lowest publication records (an independent institute must have a minimum of 20 staff) and the academy increased her budget by 15 per cent.

Even so, there is effectively no money for equipment. Because all scientists, from the academy and the universities are in the same boat, this has spawned a spirit of mutual support. Pretová has organized with the Agricultural University a shared molecular biology laboratory, in the institute building, which pools the resources of both partners. She has also struck a deal with one of the private companies in the building to use its amino acid sequencer.

Cooperation is not entirely pragmatic. Like many academy scientists, Pretová is keen to be involved in teaching the next generation of scientists. Her institute is creating a joint university-academy department for reproductive biology at the Agricultural University where many of her staff give lecture courses for token pay. She is also setting up a faculty of plant sciences in the local teacher-training college; money is available for a single post, and this is shared between Pretová, who will direct it, and two other institute scientists. Both will accept students in the next academic year.

Analogous to the struggles of the institute, the science of plant genetics in Slovakia has a history equally affected by politics. It was heavily influenced by the ideas of the Ukrainian plant physiologist, Trofim Lysenko, whose theory that genes can be modified by good husbandry was accepted as creed by the Communist Party, which in 1948 declared Mendelian genetics to be mistaken. Although the Lysenko influence had weakened by the 1960 s, plant genetics never developed as a strong science.

Pretová has helped to bring standards of Slovak plant genetics to Western levels. She says she had a lucky break when she was allowed to attend a meeting in the Netherlands in 1984. To the envy of her coworkers, she was subsequently invited by an Australian scientist, who was interested in her work on plant embryogenesis, to spend six months as a senior scientist at the University of Melbourne. It took a year to arrange a visa, but it was worth the struggle, and the experience remains a formative influence.

In Melbourne, she learnt how to get plant embryos from somatic cells in culture, an advanced technique that she brought back to Slovakia. "I was amazed by how much time scientists dedicated to talking about their research", she says, recognizing that the interest in broadcasting their work was closely linked to the need to compete for research money. She was also amazed at the long hours scientists worked - "some even worked on Christmas Day" - but saddened to realize how handicapped her com patriots were by their poor knowledge of
Western languages.

Poverty is not an ideal breeding ground for scientific innovation, but Pretová's institute will survive, because of its success in establishing itself as the core of plant sciences in a country where the development of agriculture is fundamental to the economy. It will also survive because of the support of the many foreign scientists who want to collaborate, and because of the energy and determination of its staff.
But, as Pretová says, "just when one problem is circumvented, you are dealt another blow". This autumn, there were two: the withdrawal of 5 per cent of the institute's budget (in line with the finance ministry's decree in October that the promised budget would not materialize) and the failure of the embryonic Slovak Grant Agency for Science to fund projects that had been given the highest evaluations, her own included.

A.A.

\title{
Looking separately to the West
}

Munich. Now that they are in charge of their own affairs, scientists in Central European countries do not spontaneously seek collaborations among themselves. Instead, they are looking firmly to the West.

The explanation is simple. Research standards in the West are generally high, and, more importantly, there is more money to support research. There are all sorts of permutations. Public grant-making bodies in the West support some collaboration, while there are also foundations such as Germany's Humbolt Foundation that support research. And networks of personal contacts increasingly span east and west.

Thus Václav Sklenička, director of the Institute of the Physics of Materials at Brno, has established a collaboration with the Kernforschungzentrum Karlsruhe (KFK), a national research centre in Germany, to develop new materials for use in nuclear power plants. There is no direct support from Germany, but the institute benefited from sophisticated stress-controlling and measuring equipment provided by the KFK.

But the most generous support has come from the European Union (EU), which over the past four years has offered a total of ECU262 million to support cooperative projects and networks, of which ECU110 million is allocated for this year.

That support is not part of the EU third framework programme, but is administered by separate programmes with names such as 'Copernicus'. But from the beginning of next year, cooperation with eastern Europe will become an intrinsic part of the fourth framework programme. Then there will be less money.

Only ECU220 million has been allocated to international cooperation for the four-year programme, while between a third and a half of what money there is will go to countries from the former Soviet Union.

But central eastern European countries will have the opportunity to participate, at their own cost, in all programmes of the fourth framework, including those related to industrial research which up to now have been out of bounds. Since participation allows full access to research, EU officials believe the result will be a considerable advantage to the new countries.

The EU funds available for central eastern European countries next year will be spent mostly on joint research (projects and networks) in areas of common interest. The commission of the EU had identified environmental research as the most appropriate area, but the EU committee for international cooperation, meeting last month, was not happy with the details of the commission's plan, which now has to be redrafted. This means that the call for proposals will not go out this month, as had been hoped by commissioner Antonio Ruberti, but will instead be delayed until March or even June next year.

The EU also encourages eastern European countries to cooperate among themselves, and requires all proposals to have at least two central eastern European and one west European partners.

This requirement is often criticized in the east. Sklenička, who has a Copernicus grant, says that it is not the right way to help. He fears that the eastern partners may have little to contribute to these joint ventures, and so may learn very little from them.

Others, however, are beginning to see the benefit. A group of agricultural biologists from Poland, Slovakia, Hungary and the Czech Republic, first put in touch with each other through a Copernicus network, are now teaming up once again, this time without a western European partner. They hope to be able to persuade the EU to support a programme to develop plant breeding technology in central-eastern Europe, focusing on disease and stressresistant crops.

One of the participants, Milan Bĕzdek, who is director of the Institute of Biophysics in Brno, sees this plant breeding programme as something that the east could do to help both its own agricultural development and agricultural problems faced by all countries of the world.

A.A. 